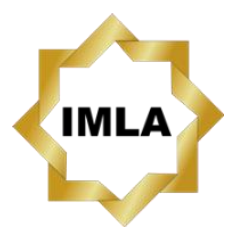

Available online:

http://journal.imla.or.id/index.php/arabi

Arabi : Journal of Arabic Studies, 3 (2), 2018, 145-156

DOI: http://dx.doi.org/10.24865/ajas.v3i2.99

\title{
EFEKTIVITAS PERMAINAN BAHASA ARAB DALAM MENINGKATKAN KEMAMPUAN MEMBACA MAHASISWA PROGRAM STUDI PENDIDIKAN BAHASA ARAB
}

\author{
Sarah Noviyanti Latuconsina, Susiawati \\ Universitas Negeri Makassar, Indonesia \\ E-mail : sarah_hlife@yahoo.com
}

\begin{abstract}
This study aimed to analyse the students' reading ability and to analyse the effectiveness of Arabic game in improving reading ability among the students of Arabic Language Education Department FBS UNM. It employed quasi-experimental method with pre-test and post-test non-equivalent control group design. The results of SPSS analysis showed that the use of Arabic game media was not effective in learning Arabic reading skills. This was evidenced by he sig value (2 tailed) of both class $A$ and $B$ post-test were 0.50, the sig value. $=0.05$. So $H_{0}$ was accepted and there was no significant difference between post-test of both experiment and control class. But this finding proves that the reading ability of the control class students was very good. Whereas in the experimental class, Arabic Reading ability was not good before treatment yet after treatment, the difference in the value of the pre-test and post-test was very significant.
\end{abstract}

Keywords: Arabic games, reading skills, Arabic language

\section{Abstrak}

Penelitian ini bertujuan untuk menganalisis tingkat kemampuan membaca mahasiswa dan efektivitas permainan bahasa Arab untuk meningkatkan keterampilan membaca mahasiswa Pendidikan Bahasa Arab semester II Fakultas Bahasa dan Sastra UNM. Penelitian ini menggunakan metode eksperimen semu (quasi eksperimental method) dengan desain "Pretest-posttest Nonequivalent Control Group". Data dianalisis secara deskriptif dan inferensial. Berdasarkan hasil analisis SPSS, penggunaan media permainan bahasa Arab tidak efektif dalam pembelajaran keterampilan membaca bahasa Arab. Hal ini berdasarkan nilai sig. (2 tailed) dari Post-test Kelas A dan Posttest Kelas $\mathrm{B}$ adalah 0.50 , nilai sig. $=0.05$ sehingga dapat disimpulkan bahwa $\mathrm{H}_{0}$ diterima maka tidak terdapat perbedaan yang signifikan antara Post-test Kelas A dan Post-test Kelas B. Namun temuan ini membuktikan kemampuan membaca mahasiswa kelas kontrol sangat baik. Sedangkan pada kelas eksperimen, kemampuan membaca bahasa Arab sebelum diberi perlakuan media permainan bahasa Arab kurang baik tetapi setelah perlakuan, perbedaan dalam nilai pre-test dan post-test sangat signifikan.

Kata Kunci: permainan bahasa Arab, keterampilan membaca, bahasa Arab 


\section{Arabi : Journal of Arabic Studies}

\section{Pendahuluan}

Perintah membaca dalam Alquran dalam Surat Al-'Alaq: 1-5 merupakan perintah Allah SWT pertama kali kepada manusia untuk membaca. Sebelum menulis dan mendengar Allah memerintahkan Nabi Muhammad SAW untuk membaca. Menurut Alwasilah (2010: 208-209), kata Iqra' adalah verba imperatif yang berarti Bacalah! Turunnya iqra' merupakan bunyi peluit dimulainya revolusi literasi yang dikomando Jibril untuk mencerdaskan manusia. Membaca mengandung serentang makna kognitif, afektif, dan motorik seperti mengetahui, meneliti, mengamati, merenungkan, dan merasakan. Iqra'sebagai verba transitif dalam ayat ini tidak diikuti objek. Ini ditafsirkan bahwa membaca di sini tidak terbatas hanya pada tulisan, tetapi merujuk pada objek yang lebih umum termasuk alam semesta.

Menurut Mujib dan Rahmawati (2013: 60) membaca adalah proses aktif dari pikiran yang dilakukan melalui mata terhadap bacaan. Dalam kegiatan membaca, pembaca memproses informasi dari teks yang dibaca untuk memperoleh makna. Selanjutnya Asrori dan Ahsanuddin (2015: 143) mengatakan bahwa kemahiran membaca merupakan kemahiran ketiga dari empat kemahiran berbahasa dilihat dari pemerolehannya oleh manusia. Membaca pada dasarnya merupakan proses menerjemahkan lambang tulis ke dalam makna, dan bukan sekadar mengubah lambang tulis menjadi lambang bunyi. Pada hakikatnya, membaca merupakan proses mental untuk memperoleh informasi yang terkandung dalam bahan tertulis.

Keterampilan adalah suatu kemampuan dalam melakukan sesuatu. Seseorang dikatakan mampu apabila ia bisa melakukan sesuatu yang harus ia lakukan. Dalam Kamus Besar Bahasa Indonesia (Alwi, 2007: 1180) keterampilan adalah kecakapan untuk menyelesaikan tugas.

Keterampilan membaca merupakan materi terpenting di antara materi-materi pelajaran (Rosyidi \& Ni'mah, 2011: 95). Siswa yang unggul dalam pelajaran membaca mereka unggul dalam pelajaran yang lain pada semua jenjang pendidikan. Membaca adalah kegiatan yang meliputi pola berpikir, menilai, menganalisis, dan memecahkan masalah.

Dalam beberapa pengamatan dan penelitian pembelajaran bahasa Arab menurut Mujib \& Rahmawati ( 2013: 67), guru bahasa Arab terlalu banyak menyuapi atau memberikan materi, tetapi kurang menyuruh siswa untuk aktif membaca, menyimak, menulis, dan berbicara. Proses belajar mengajar di kelas kurang relevan dengan yang diharapkan. Akibatnya kemampuan membaca siswa rendah. Tujuan dari membaca adalah pemahaman, maka apabila orang tidak dapat membaca dengan baik, maka ia tidak dapat menyampaikan isi atau informasi dari suatu bacaan (Ketong, dkk, 2018).

Membaca teks bahasa Arab bagi para pemula merupakan hal yang sulit dilakukan. Mahasiswa Program Studi Pendidikan Bahasa Arab Universitas Negeri Makassar pada semester awal kerap kali menghadapi kesulitan dalam membaca bahasa Arab. Ini dikarenakan bunyi atau pengucapan bahasa Arab yang berbeda dengan bahasa Indonesia, serta perbedaan arah tulisan bahasa Arab yang dimulai dari kanan ke kiri. Sedangkan dalam bahasa Indonesia, mahasiswa dapat membaca dengan cepat karena kebiasaan membaca dari kiri ke kanan. Faktor lain yang diduga merupakan kesulitan membaca bahasa Arab adalah latar belakang pendidikan mahasiswa itu sendiri. Sebagian besar mahasiswa Prodi Pendidikan Bahasa Arab berlatar belakang pendidikan SMA yang tidak pernah belajar bahasa Arab secara intensif di sekolah mereka sebelumnya.

Hidup di dunia adalah permainan. Dalam kitab suci al-Qur'an Allah berfirman yang artinya: "Kehidupan dunia ini adalah main-main dan senda gurau belaka...."(Q.S Al-an'am: 32). Jikalau Allah sudah menyatakan bahwa kehidupan dunia ini pada dasarnya adalah main-main, maka dalam semua aktivitas hidup di dunia ini tidak bisa terlepas dari unsur bermain. Demikian halnya dalam kegiatan belajar dan pembelajaran, termasuk di dalamnya kegiatan belajar dan pembelajaran bahasa Arab. Permainan merupakan bagian yang sangat penting dalam kehidupan manusia. Dalam kehidupan sehari-hari, tampak bahwa setiap orang baik laki-laki ataupun perempuan, anak-anak dan orang dewasa, kaya dan miskin semuanya menyukai permainan (Asrori, 2013: 2) 
Penggunaan bentuk-bentuk permainan dalam pembelajaran dapat memberi iklim yang menyenangkan dalam proses belajar (Mujib \& Rahmawati, 2013: 77), sehingga proses pembelajaran dapat dilakukan dengan santai tanpa adanya keterpaksaan. Dengan cara santai, selsel otak mereka dapat berkembang. Selanjutnya mereka dapat menyerap informasi dan memperoleh kesan yang mendalam terhadap materi dan dapat disimpan terus dalam ingatan jangka panjang.

Tujuan penelitian ini adalah 1) untuk menganalisis tingkat kemampuan membaca mahasiswa Pendidikan Bahasa Arab semester II TA 2016/2017 Fakultas Bahasa dan Sastra UNM dengan menggunakan permainan bahasa, serta 2) menunjukkan efektivitas permainan bahasa Arab untuk meningkatkan keterampilan membaca pada mahasiswa Pendidikan Bahasa Arab semester II TA 2016/2017 Fakultas Bahasa dan Sastra UNM.

\section{Peningkatan Keterampilan Membaca Bahasa Arab}

Keterampilan membaca dalam bahasa Arab disebut mahärah al-qira'ah. Keterampilan membaca terkait dengan dua aspek, yaitu kemampuan mengubah lambang tulis menjadi bunyi dan menangkap arti dari seluruh situasi yang dilambangkan dengan lambang-lambang bunyi tersebut (Mujib \& Rahmawati, 2013: 60). Abdur Rahman ibn Abrahim al-Fauzan menyatakan bahwa (2011: 194):

$$
\begin{aligned}
& \text { "القراءة هي تحويل النظام اللغوي من الرموز المرئية (الحروف) إلى مدلولاته. وتعد القراءة مصدرا أساسيا لتعلم اللغة : }
\end{aligned}
$$

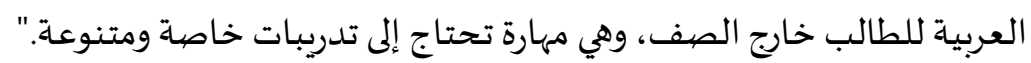

Membaca adalah mengubah susunan bahasa dari simbol-simbol huruf ke petunjuk (makna) bacaan tersebut. Membaca merupakan sumber (materi) dasar untuk belajar bahasa Arab bagi siswa yang bukan penutur asli, yakni membaca merupakan keterampilan yang membutuhkan latihanlatihan khusus dan beragam.

Upaya untuk meningkatkan keterampilan membaca bahasa Arab adalah dengan memperbanyak latihan membaca secara terus menerus. Berbagai macam qirā'ah dapat dilakukan untuk meningkatkan keterampilan membaca. Membaca intensif (qirāah mukatstsafah) yaitu membaca dengan menggunakan media untuk mempelajari kata-kata baru dan susunan kalimat baru (Abdullah, 2008: 100). Selain itu ada juga jenis membaca ekstensif ( qirā'ah muwassa'ah) yang disebut juga dengan membaca sempurna. Hal ini disebabkan membaca ekstensif merupakan penyempurnaan dari membaca intensif dan umumnya membaca jenis ini dengan media ceritacerita panjang maupun pendek (Abdullah, 2008: 101).

\section{Efektivitas Permainan Bahasa}

Permainan bahasa menurut Mujib dan Rahmawati (2011: 32) adalah cara mempelajari bahasa melalui permainan. Permaian bahasa bukan merupakan aktivitas tambahan untuk bergembira semata, tetapi permainan ini dapat digolongkan dalam pengajaran dan pembelajaran yang bertujuan memberikan kesempatan kepada siswa untuk mengaplikasikan kemahiran berbahasa yang telah dipelajari.

Asrori dan Ahsanuddin (2015: 48) menambahkan bahwa tidak ada perbedaan yang tegas antara latihan berbahasa dengan permainan berbahasa. Prasyarat pokok agar suatu kegiatan latihan berbahasa dapat disebut sebagai permainan berbahasa adalah adanya unsur hiburan (refreshing) dan bersaing. Guru juga dapat melakukan modifikasi tertentu terhadap kegiatan latihan berbahasa sehingga menjadi permainan berbahasa.

\section{Metode Penelitian}

Metode dalam penelitian ini adalah metode eksperimen semu atau quasi eksperimental method dengan desain "Pretest-posttest Nonequivalen Control Group" (Sugiyono, 2010: 116). Penelitian ini mempunyai dua variabel, yaitu variabel independen dan variabel dependen. Variabel independen dalam penelitian ini adalah penggunaan permainan bahasa dalam peningkatan 


\section{Arabi : Journal of Arabic Studies}

kemahiran membaca mahasiswa semester II Prodi Pendidikan Bahasa Arab FBS UNM. Sedangkan variable dependen dalam penelitian ini adalah kemampuan hasil membaca mahasiswa semester II Prodi Pendidikan Bahasa Arab FBS UNM.

Desain penelitian yang digunakan dalam penelitian ini adalah jenis penelitian deskriptif kuantitatif. Penelitian ini dilaksanakan pada Program Studi Pendidikan bahasa Arab Fakultas Bahasa dan Sastra Universitas Negeri Makassar. Populasi penelitian ini adalah seluruh mahasiswa Prodi Pendidikan Bahasa Arab Fakultas Bahasa dan Sastra Universitas Negeri Makassar Angkatan 2016 yang memprogramkan mata kuliah Muthāla'ah I. Teknik pengambilan sampling menggunakan teknik cluster sampling (Setyosari, 2015: 224). Adapun sampel penelitian yang terpilih adalah kelas B (25 orang) sebagai kelas eksperimen dan kelas A (25 orang) sebagai kelas kontrol.

Teknik pengumpulan data menggunakan instrumen pre-test dan post-test. Adapun tes yang dimaksudkan adalah tes membaca bahasa Arab dengan memberikan harakat atau tanda baca pada bacaan. Selanjutnya menganalisis hasil pre-test dan post-test dengan menggunakan analisis data deskriptif statistik dan inferensial statistik. Sedangkan untuk menguji hipotesis penelitian dengan menggunakan uji-t. Namun, sebelum melakukan pengujian tersebut dilakukan uji normalitas dengan menggunakan uji F (Fisher). Sebelum menentukan uji normalitas data dan homogenitas maupun uji hipotesis ditentukan terlebih dahulu nilai rata-rata (mean), simpangan baku dan varian.

\section{Hasil Penelitian}

\section{Analisis Statistik Deskriptif \\ Pre-test Kelas Eksperimen}

Berdasarkan nilai yang diperoleh dari hasil pre-test mahasiswa Prodi Pendidikan Bahasa Arab FBS UNM kelas B sebagai kelas eksperimen, rata-rata (mean) dari 25 mahasiswa adalah 54. Nilai tertinggi 85 dan nilai terendah adalah 40. Dari hasil perhitungan diperoleh rentangan 7.5 kemudian dibulatkan menjadi 8 dengan jumlah interval skor 6 .

Tabel 1. Distribusi Frekuensi dan Persentase Nilai Pre-Test Mahasiswa Kelas Eksperimen

\begin{tabular}{|c|c|c|c|}
\hline No & Interval Skor & Frekuensi & Persentase (\%) \\
\hline 1 & $81-88$ & 1 & 4 \\
\hline 2 & $73-80$ & 1 & 4 \\
\hline 3 & $65-72$ & 4 & 16 \\
\hline 4 & $57-64$ & 6 & 24 \\
\hline 5 & $48-56$ & 8 & 32 \\
\hline 6 & $40-47$ & 5 & 20 \\
\hline \multicolumn{2}{|c|}{ Jumlah } & $\mathbf{2 5}$ & $\mathbf{1 0 0}$ \\
\hline
\end{tabular}

Data frekuensi dan persentase nilai pre-test kelas eksperimen berdasarkan tabel di atas menunjukkan bahwa dari 25 mahasiswa terdapat 5 orang (20\%) memeroleh nilai pada interval skor dengan rentangan 40-47. Kemudian 8 mahasiswa (32\%) memeroleh nilai pada interval skor dengan rentangan 48-56. 6 mahasiswa (24\%) memeroleh nilai pada interval skor dengan rentangan 57-64. 4 mahasiswa (16\%) memeroleh nilai pada interval skor dengan rentangan 65-72. 1 mahasiswa (4\%) memeroleh nilai pada interval skor dengan rentangan 73-80. Dan 1 mahasiswa (4\%) memeroleh nilai pada interval skor dengan rentangan 81-88. Ini membuktikan bahwa tingkat kemampuan membaca bahasa Arab mahasiswa kelas B Prodi Pendidikan Bahasa Arab dalam mengerjakan soal pre-test termasuk rendah. 


\section{Pre-test Kelas Kontrol}

Berdasarkan nilai yang diperoleh dari hasil pre-test mahasiswa Prodi Pendidikan Bahasa Arab FBS UNM kelas A sebagai kelas kontrol, rata-rata (mean) dari 30 mahasiswa adalah 62,6 kemudian dibulatkan menjadi 63 (nilai tertinggi adalah 85 dan nilai terendah adalah 40). Dari hasil perhitungan diperoleh rentangan 8 dengan jumlah interval skor 6 . Adapun distribusi frekuensi data dapat dilihat pada tabel berikut:

Tabel 2. Distribusi Frekuensi dan Persentase Nilai Pre-Test Mahasiswa Prodi Pendidikan Bahasa Arab FBS UNM Kelas Kontrol

\begin{tabular}{|c|c|c|c|}
\hline No & Interval Skor & Frekuensi & Persentase (\%) \\
\hline 1 & $80-87$ & 4 & 13.3 \\
\hline 2 & $72-79$ & 4 & 13.3 \\
\hline 3 & $64-71$ & 7 & 23.3 \\
\hline 4 & $56-63$ & 2 & 6.6 \\
\hline 5 & $48-55$ & 12 & 40 \\
\hline 6 & $40-47$ & 1 & 3.3 \\
\hline \multicolumn{2}{|c|}{ Jumlah } & 30 & 100 \\
\hline
\end{tabular}

Data frekuensi dan persentase nilai pre-test kelas kontrol berdasarkan tabel di atas menunjukkan bahwa dari 30 mahasiswa terdapat 1 mahasiswa $(3.3 \%)$ memeroleh nilai pada interval skor dengan rentangan 40-47. Kemudian 12 mahasiswa (40\%) memeroleh nilai pada interval skor dengan rentangan 48-55. 2 mahasiswa (6.6\%) memeroleh nilai pada interval skor dengan rentangan 56-63. 7 mahasiswa (23.3\%) memeroleh nilai pada interval skor dengan rentangan 64-7. 4 mahasiswa (13.3\%) memeroleh nilai pada interval skor dengan rentangan 72-79, dan 4 mahasiswa (13.3\%) memeroleh nilai pada interval skor dengan rentangan 80-87. Berdasarkan hasil pre-test yang diberikan kepada mahasiswa, dapat disimpulkan bahwa tingkat kemampuan membaca bahasa Arab mahasiswa dalam mengerjakan soal pre-test termasuk rendah.

Setelah mahasiswa Kelas B atau kelas eksperimen diberi perlakuan dengan menggunakan media permainan bahasa Arab, mereka diberi post-test untuk melihat tingkat kemampuan membaca bahasa Arab. Begitu juga dengan kelas A atau kelas kontrol, diberi post-test pada akhir pertemuan untuk mengetahui sejauh mana kemampuan membaca bahasa Arab kelas kontrol tanpa diberi perlakuan.

\section{Post-test Kelas Eksperimen}

Berdasarkan nilai yang diperoleh dari hasil post-test mahasiswa Prodi Pendidikan Bahasa Arab FBS UNM kelas B sebagai kelas eksperimen, rata-rata (mean) dari 25 siswa adalah 87.44 (nilai tertinggi adalah 98 dan terendah adalah 78). Dari hasil perhitungan diperoleh rentangan 3 dengan jumlah interval skor adalah 6 . Adapun distribusi frekuensi data dapat dilihat pada tabel di bawah ini:

Tabel 3. Distribusi Frekuensi dan Persentase Nilai Post-Test Mahasiswa Prodi Pendidikan Bahasa Arab FBS UNM Kelas Eksperimen

\begin{tabular}{|c|c|c|c|}
\hline No & Interval Skor & Frekuensi & Persentase (\%) \\
\hline 1 & $96-98$ & 1 & 4 \\
\hline 2 & $93-95$ & 4 & 16 \\
\hline
\end{tabular}


Arabi : Journal of Arabic Studies

\begin{tabular}{|c|c|c|c|}
\hline 3 & $90-92$ & 5 & 20 \\
\hline 4 & $87-89$ & 2 & 8 \\
\hline 5 & $84-86$ & 8 & 32 \\
\hline 6 & $81-83$ & 0 & 0 \\
\hline 7 & $78-80$ & 5 & 20 \\
\hline \multicolumn{2}{|c|}{ Jumlah } & 25 & 100 \\
\hline
\end{tabular}

Tabel di atas menunjukkan bahwa dari 25 mahasiswa, 5 orang (20\%) memeroleh nilai pada interval skor dengan rentangan 78-80 dan 90-92. Kemudian tidak ada mahasiswa yang memeroleh nilai pada interval skor dengan rentangan 81-83. Ada 8 mahasiswa (32\%) memeroleh nilai pada interval skor dengan rentangan 84-86. 2 mahasiswa (8\%) memeroleh nilai pada interval skor dengan rentangan 87-89. 4 mahasiswa (16\%) memeroleh nilai pada interval skor dengan rentangan 93-95. Dan 1 mahasiswa (4\%) memeroleh nilai pada interval skor dengan rentangan 96-98. Berdasarkan hasil tes akhir yang diberikan kepada mahasiswa, dapat disimpulkan bahwa tingkat kemampuan membaca bahasa Arab dalam mengerjakan soal post-test sangat baik

\section{Post-test Kelas Kontrol}

Berdasarkan nilai yang diperoleh dari hasil post-test mahasiswa Prodi Pendidikan Bahasa Arab FBS UNM kelas A sebagai kelas kontrol, rata-rata (mean) dari 30 siswa adalah 87.6 (nilai tertinggi adalah 98 dan terendah adalah 80). Dari hasil perhitungan diperoleh rentangan 3 dengan jumlah interval skor adalah 6. Adapun distribusi frekuensi data dapat dilihat pada tabel di bawah ini:

Tabel 4. Distribusi Frekuensi dan Persentase Nilai Post-Test Mahasiswa Prodi Pendidikan Bahasa Arab FBS UNM Kelas Kontrol

\begin{tabular}{|c|c|c|c|}
\hline No & Interval Skor & Frekuensi & Persentase (\%) \\
\hline 1 & $98-100$ & 1 & 3.33 \\
\hline 2 & $95-97$ & 4 & 13.3 \\
\hline 3 & $92-94$ & 2 & 6.6 \\
\hline 4 & $89-91$ & 8 & 26.6 \\
\hline 5 & $86-88$ & 2 & 6.6 \\
\hline 6 & $83-85$ & 5 & 16.6 \\
\hline 7 & $80-82$ & 8 & 26.6 \\
\hline \multicolumn{2}{|c|}{ Jumlah } & 30 & 100 \\
\hline
\end{tabular}

Data frekuensi dan persentase nilai post-test kelas kontrol berdasarkan tabel di atas menunjukkan bahwa dari 30 mahasiswa, 8 orang $(26.6 \%)$ memeroleh nilai pada interval skor dengan rentangan 80-82 dan 89-91. Kemudian 5 mahasiswa (16.6\%) yang memeroleh nilai pada interval skor dengan rentangan 83-85. Ada 2 mahasiswa (6.6\%) memeroleh nilai pada interval skor dengan rentangan 86-88 dan 92-94. 4 mahasiswa (13.3) memeroleh nilai pada interval skor dengan rentangan 95-97. Dan 1 mahasiswa (3.33\%) memeroleh nilai pada interval skor dengan rentangan 98-100. Berdasarkan hasil tes akhir yang diberikan kepada mahasiswa, dapat disimpulkan bahwa tingkat kemampuan membaca bahasa Arab dalam mengerjakan soal post-test sangat baik. 


\section{Analisis Statistik Inferensial}

Tabel 5. Uji Normalitas pre-test kelas eksperimen

\begin{tabular}{|c|c|c|c|}
\hline \multirow{2}{*}{ Kelas } & \multicolumn{3}{|c|}{ Kolmogorov-Smirnova } \\
\hline & Statistic & Df & Sig. \\
\hline 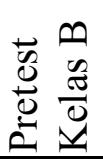 & .204 & 25 & .008 \\
\hline
\end{tabular}

Sebuah data dapat dikatakan terdistribusi normal apabila nilai sig. ${ }^{-} 0.05$ dan tidak berdistribusi normal jika nilai sig. 0.05 . Berdasarkan tabel di atas, nilai pre-test kelas B memiliki nilai sig. 0.008 yang berarti nilai sig. 0.05 maka nilai pre-test kelas B berdistribusi Normal atau sesuai dengan kemampuan mahasiswa.

\section{Tabel 6. Uji Normalitas Pre-test Kelas Kontrol}

\begin{tabular}{|c|c|c|c|}
\hline \multirow{2}{*}{ Kelas } & \multicolumn{3}{|c|}{ Kolmogorov-Smirnov $^{\mathrm{a}}$} \\
\hline & Statistic & Df & Sig. \\
\hline 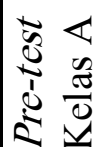 & .210 & 30 & .002 \\
\hline
\end{tabular}

Berdasarkan tabel di atas, nilai pre-test kelas A memiliki nilai sig 0.002 yang berarti nilai sig. 0.05 maka nilai pre-test kelas A tidak berdistribusi Normal atau tidak sesuai dengan kemampuan mahasiswa.

\section{Uji Homogenitas}

Tabel 7. Varians Pre-test kelas eksperimen dan kontrol

\begin{tabular}{|l|l|l|l|}
\hline $\begin{array}{l}\text { Levene } \\
\text { Statistic }\end{array}$ & df1 & df2 & Sig. \\
\hline 464 & 1 & 53 & .499 \\
\hline
\end{tabular}

Sebuah data dikatakan Homogen apabila nilai sig. 0.05 dan tidak Homogen jika nilai sig. 0.05. Berdasarkan data di atas maka dapat disimpulkan bahwa kedua sampel pre-test baik kelas eksperimen maupun kontrol memiliki varian yang sama atau homogen karena nilai sig. untuk test homogenyā 0.05 .

\section{Pengujian Hipotesis}

Kelas Eksperimen (Pretest - Postest)

Untuk mengetahui tingkat perbedaan kemampuan membaca mahasiswa kelas eksperimen (Kelas B), maka dilakukan uji hipotesis dengan SPSS sebagai berikut: 
Tabel 8. Paired Samples Test Kelas Eksperimen

\begin{tabular}{|c|c|c|c|c|c|c|c|c|c|}
\hline & & \multicolumn{5}{|c|}{ Paired Differences } & \multirow[b]{3}{*}{$\mathrm{t}$} & \multirow[b]{3}{*}{$\mathrm{df}$} & \multirow[t]{3}{*}{$\begin{array}{l}\text { Sig. (2- } \\
\text { tailed) } \\
\end{array}$} \\
\hline & & \multirow[b]{2}{*}{ Mean } & \multirow{2}{*}{$\begin{array}{c}\text { Std. } \\
\text { Deviation }\end{array}$} & \multirow{2}{*}{$\begin{array}{l}\text { Std. } \\
\text { Error } \\
\text { Mean }\end{array}$} & \multicolumn{2}{|c|}{$\begin{array}{c}95 \% \text { Confidence } \\
\text { Interval of the } \\
\text { Difference }\end{array}$} & & & \\
\hline & & & & & Lower & Upper & & & \\
\hline$\overline{\bar{a}}$ & $\begin{array}{l}\text { Pretest_- } \\
\text { B - } \\
\text { Posttest_ } \\
\text { B }\end{array}$ & 31.44000 & 10.88990 & 2.17798 & 26.94487 & 35.93513 & 14.435 & 24 & .000 \\
\hline $\overrightarrow{\bar{\pi}}$ & $\begin{array}{l}\text { Pretest_ } \\
\text { B - } \\
\text { Posttest_ } \\
\text { B }\end{array}$ & 31.44000 & 10.88990 & 2.17798 & 26.94487 & 35.93513 & 14.435 & 24 & .000 \\
\hline
\end{tabular}

Dengan kriteria pengujian sebagai berikut:

$\mathrm{H}_{0}=\mu_{1}=\mu_{2}$ vs $\mathrm{H}_{1}=\mu_{1} \neq \mu_{2}$

$\mathrm{H}_{0}=$ Tidak Terdapat Perbedaan Signifikan antara Pre-test dan Post-test

$\mathrm{H}_{1}=$ Terdapat Perbedaan Signifikan antara Pre-test dan Post-test

$\mathrm{H}_{0}$ diterima jika nilai sig. (2 tailed) 0.05 , sedangkan $\mathrm{H}_{0}$ ditolak jika nilai sig. (2 Tailed) 0.05

Berdasaran tabel di atas nilai sig. (2 tailed) dari Pre-test dan Post-test kelas B adalah 0.00, nilai sig. 0.05 sehingga dapat disimpulkan bahwa $\mathrm{H}_{0}$ ditolak maka Terdapat Perbedaan yang signifikan antara Pre-test dan Post-test.

Kelas Kontrol (Pre-test - Post-test)

Tabel 9. Paired Samples Test Kelas Kontrol

\begin{tabular}{|c|c|c|c|c|c|c|c|c|c|}
\hline & \multicolumn{5}{|c|}{ Paired Differences } & \multirow[b]{3}{*}{$\mathrm{T}$} & \multirow[b]{3}{*}{$\mathrm{df}$} & \multirow{3}{*}{$\begin{array}{l}\text { Sig. (2- } \\
\text { tailed) }\end{array}$} \\
\hline & & \multirow[b]{2}{*}{ Mean } & \multirow{2}{*}{$\begin{array}{c}\text { Std. } \\
\text { Deviation }\end{array}$} & \multirow{2}{*}{$\begin{array}{l}\text { Std. } \\
\text { Error } \\
\text { Mean }\end{array}$} & \multicolumn{2}{|c|}{$\begin{array}{c}95 \% \text { Confidence } \\
\text { Interval of the } \\
\text { Difference }\end{array}$} & & & \\
\hline & & & & & Lower & Upper & & & \\
\hline : & $\begin{array}{l}\text { Pretest__ } \\
\text { A - } \\
\text { Postest_- } \\
\text { A }\end{array}$ & 24.96667 & 9.37525 & 1.71168 & 21.46589 & 28.46744 & 14.586 & 29 & .000 \\
\hline
\end{tabular}

Dengan kriteria pengujian sebagai berikut:

$\mathrm{H}_{0}=\mu_{1}=\mu_{2}$ vs $\mathrm{H}_{1}=\mu_{1} \neq \mu_{2}$

$\mathrm{H}_{0}=$ Tidak Terdapat Perbedaan Signifikan antara Pre-test dan Post-test

$\mathrm{H}_{1}=$ Terdapat Perbedaan Signifikan antara Pre-test dan Post-test

$\mathrm{H}_{0}$ diterima jika nilai sig. (2 tailed) 0.05 , sedangkan $\mathrm{H}_{0}$ ditolak jika nilai sig. (2 Tailed) 0.05 . 
Berdasarkan tabel di atas nilai sig. (2 tailed) dari Pre-test dan Post-test kelas A adalah 0.00, nilai sig. 0.05 sehingga dapat disimpulkan bahwa $\mathrm{H}_{0}$ ditolak maka terdapat perbedaan yang signifikan antara Pre-test dan Post-test.

\section{Post-test (Kelas Eksperimen dan Kelas Kontrol)}

Tabel 10. Paired Samples Test Kelas Eksperimen dan Kontrol

\begin{tabular}{|c|c|c|c|c|c|c|c|c|c|}
\hline & \multicolumn{5}{|c|}{ Paired Differences } & \multirow[b]{3}{*}{$\mathrm{t}$} & \multirow[b]{3}{*}{ Df } & \multirow{3}{*}{$\begin{array}{l}\text { Sig. (2- } \\
\text { tailed) }\end{array}$} \\
\hline & & \multirow[b]{2}{*}{ Mean } & \multirow{2}{*}{$\begin{array}{c}\text { Std. } \\
\text { Deviation }\end{array}$} & \multirow{2}{*}{$\begin{array}{l}\text { Std. } \\
\text { Error } \\
\text { Mean }\end{array}$} & \multicolumn{2}{|c|}{$\begin{array}{c}95 \% \text { Confidence } \\
\text { Interval of the } \\
\text { Difference }\end{array}$} & & & \\
\hline & & & & & Lower & Upper & & & \\
\hline כ. & $\begin{array}{l}\text { Post- } \\
\text { test_A- } \\
\text { Post- } \\
\text { test_B }\end{array}$ & 7.00000 & 16.95582 & 3.39116 & .00098 & 13.99902 & 2.064 & 24 & .050 \\
\hline
\end{tabular}

Dengan kriteria pengujian sebagai berikut:

$\mathrm{H}_{0}=\mu_{1}=\mu_{2}$ vs $\mathrm{H}_{1}=\mu_{1} \neq \mu_{2}$

$\mathrm{H}_{0}=$ Tidak Terdapat Perbedaan Signifikan antara Post-test Kelas A dan Post-test Kelas B

$\mathrm{H}_{1}=$ Terdapat Perbedaan Signifikan antara Post-test Kelas A dan Post-test Kelas B

$\mathrm{H}_{0}$ diterima jika nilai sig. (2 tailed) 0.05 , sedangkan $\mathrm{H}_{0}$ ditolak jika nilai sig. (2 Tailed) 0.05

Berdasarkan tabel di atas nilai sig. (2 tailed) dari Post-test Kelas A dan Post-test Kelas B adalah 0.50 , nilai sig. $=0.05$ sehingga dapat disimpulkan bahwa $\mathrm{H}_{0}$ diterima maka tidak terdapat perbedaan yang signifikan antara Post-test Kelas A dan Post-test Kelas B. Dengan demikian $\mathrm{H}_{0}$ yang berbunyi: tidak ada perbedaan yang signifikan antara kemampuan membaca bahasa Arab mahasiswa yang diajar dengan menggunakan media permainan bahasa Arab dan mahasiswa yang tidak diajar dengan menggunakan media permainan bahasa Arab diterima. Konsekuensi dari diterimanya $\mathrm{H}_{0}$ maka $\mathrm{H}_{1}$ yang berbunyi: ada perbedaan yang signifikan antara kemampuan membaca bahasa Arab mahasiswa yang diajar dengan menggunakan media permainan bahasa Arab dan mahasiswa yang tidak diajar dengan menggunakan media permainan bahasa Arab ditolak.

Penolakan $\mathrm{H}_{1}$ membuktikan bahwa media permainan bahasa Arab tidak efektif dalam pembelajaran kemampuan membaca bahasa Arab Mahasiswa Prodi Pendidikan Bahasa Arab angkatan 2016 Fakultas Bahasa dan Sastra Universitas Negeri Makassar.

Dengan kriteria pengujian sebagai berikut:

$\mathrm{H}_{0}=\mu_{1}=\mu_{2}$ vs $\mathrm{H}_{1}=\mu_{1} \neq \mu_{2}$

$\mathrm{H}_{0}=$ Tidak Terdapat Perbedaan Signifikan antara Pre-test dan Post-test

$\mathrm{H}_{1}=$ Terdapat Perbedaan Signifikan antara Pre-test dan Post-test

$\mathrm{H}_{0}$ diterima jika nilai sig. (2 tailed) ${ }^{-} 0.05$, sedangkan $\mathrm{H}_{0}$ ditolak jika nilai sig. (2 Tailed) 0.05 .

Berdasarkan tabel di atas nilai sig. (2 tailed) dari Pre-test dan Post-test kelas A adalah 0.00, nilai sig. 0.05 sehingga dapat disimpulkan bahwa $\mathrm{H}_{0}$ ditolak maka terdapat perbedaan yang signifikan antara Pre-test dan Post-test.

\section{Pembahasan}

Dalam pembahasan ini perlu dikemukakan bahwa membaca merupakan salah satu keterampilan yang tidak kalah penting dengan tiga maharah lainnya. Membaca atau dalam bahasa 


\section{Arabi : Journal of Arabic Studies}

Arab disebut mahärah al-qirā'ah merupakan salah satu kemampuan berbahasa yang bersifat reseptif (Rosyidi \& Ni'mah, 2011: 134). Ini berarti bahwa orang yang mempelajari keterampilan membaca harus mengamati terlebih dahulu, kemudian memahami, dan memikirkan. Bahruddin (2017: 174) menyatakan bahwa tujuan utama mempelajari mahärah al-qirā'ah adalah pemahaman. Mahasiswa atau murid dituntut untuk memahami teks bacaan dengan baik. Setelah memahami teks bacaan dengan baik, maka mahasiswa atau siswa dapat menyampaikan apa yang dipahaminya baik secara lisan maupun tulisan. Hal ini juga sejalan dengan teori yang dikemukakan Dalman (2014: 5) bahwa membaca merupakan suatu kegiatan atau proses kognitif yang berupaya untuk menemukan berbagai informasi yang terdapat dalam tulisan. Membaca merupakan proses berpikir untuk memahami isi teks yang dibaca.

Dalam suatu pembelajaran perlu adanya unsur-unsur yang mendukung pembelajaran tersebut, seperti kurikulum, metode, materi, media maupun evaluasi. Media pembelajaran mempunyai peran penting dalam proses pembelajaran. Menurut Rosyidi dan Ni'mah (2011: 107) dengan menggunakan media pembelajaran secara tepat dan bervariasi dapat berguna untuk menimbulkan gairah atau semangat belajar, memungkinkan interaksi yang lebih antara peserta didik dengan lingkungan dan kenyataan, memungkinkan peserta belajar sendiri-sendiri menurut kemampuan dan minatnya, serta memudahkan untuk mengenali informasi yang dibutuhkan.

Salah satu media yang digunakan dalam penelitian ini adalah media permainan bahasa. Permainan bahasa menurut Mujib dan Rahmawati (2011: 32) adalah cara mempelajari bahasa melalui permainan. Permaian bahasa bukan merupakan aktivitas tambahan untuk bergembira semata, tetapi permainan ini dapat digolongkan dalam pengajaran dan pembelajaran yang bertujuan memberikan kesempatan kepada siswa untuk mengaplikasikan kemahiran berbahasa yang telah dipelajari.

Pembelajaran dalam penelitian ini dilakukan selama 1 semester atau 16 kali pertemuan termasuk Pre-test dan Post-test. Dalam pembelajaran tersebut, kedua kelas diajar menggunakan media yang berbeda. Pada kelas eksperimen mahasiswa diajar dengan menggunakan media permainan bahasa Arab sedangkan pada kelas kontrol mahasiswa diajar dengan tidak menggunakan media permainan bahasa Arab. Dalam hal ini hanya menggunakan media buku, papan tulis, dan spidol.

Hasil pre-test menunjukkan bahwa nilai rata-rata (mean) untuk kelas eksperimen 54 dan kelas kontrol 62.6 dalam kemampuan membaca bahasa Arab mahasiswa semester II angkatan 2016 Prodi Pendidikan Bahasa Arab Fakultas Bahasa dan Sastra Universitas Negeri Makassar, jumlah skor perolehan untuk kelas eksperimen adalah 1350 dan kelas kontrol adalah 1880. Hasil uji normalitas pada data pre-test kedua kelas menunjukkan bahwa nilai pre-test kelas A memiliki nilai sig 0.002 yang berarti nilai sig. 0.05 maka nilai pre-test A tidak berdistribusi normal, artinya tes yang diberikan tidak sesuai dengan kemampuan mahasiswa. Sedangkan kelas B memiliki nilai sig. 0.008 yang berarti nilai sig. 0.05 maka nilai pre-test kelas B berdistribusi normal, yang artinya tes yang diberikan sesuai dengan kemampuan mahasiswa.

Berdasarkan hasil post-test kelas eksperimen, penggunaan media permainan bahasa Arab berdampak positif pada peningkatan kemampuan membaca bahasa Arab mahasiswa. Hal ini bisa dilihat dari perolehan nilai post-test mahasiswa, pada kelas eksperimen nilai terendah yaitu 78 dan nilai tertinggi 98 dengan nilai rata-rata 87.44, sedangkan pada kelas kontrol diperoleh nilai 80 untuk nilai terendah dan 98 untuk nilai tertinggi dengan nilai rata-rata 87,6. Lebih dari itu, tingkat kemampuan membaca bahasa Arab mahasiswa dalam mengerjakan soal pre-test pada kelas eksperimen sebanyak (32.56\%). Setelah diberikan perlakuan, persentasenya lebih meningkat $(99,83 \%)$. Walaupun tingkat kemampuan membaca bahasa Arab kelas kontrol dan kelas eksperimen tidak terdapat perbedaan yang signifikan, namun perlakuan pembelajaran dengan menggunakan media permainan bahasa Arab dianggap cukup membantu meningkatkan kemampuan membaca bahasa Arab mahasiswa. 
Pada uji normalitas data pre-test kelas kontrol, nilai pre-test kelas A memiliki nilai sig 0.002 yang berarti nilai sig. 0.05 maka nilai pre-test kelas A tidak berdistribusi normal. Hal ini menandakan bahwa tes yang diberikan tidak sesuai dengan kemampuan mahasiswa. Sedangkan pada uji normalitas kelas eksperimen, nilai pre-test kelas B memiliki nilai sig. 0.008 yang berarti nilai sig. ${ }^{-} 0.05$ maka nilai pre-test kelas B berdistribusi normal sehingga distribusi datanya dinyatakan normal yang artinya tes yang diberikan sesuai dengan kemampuan mahasiswa.

Hasil analisis di atas, dilanjutkan dengan uji-t untuk melihat hasil akhir dari penelitian ini. Berdasarkan tabel 11 (halaman 39) di atas nilai sig. (2 tailed) dari Post-test Kelas A dan Post-test Kelas $\mathrm{B}$ adalah 0.50 , nilai sig. $=0.05$ sehingga dapat disimpulkan bahwa $\mathrm{H}_{0}$ diterima maka Tidak Terdapat Perbedaan yang signifikan antara Post-test Kelas A dan Post-test Kelas B.

Dengan demikian $\mathrm{H}_{0}$ yang berbunyi: tidak ada perbedaan yang signifikan antara kemampuan membaca bahasa Arab mahasiswa yang diajar dengan menggunakan media permainan bahasa Arab dan mahasiswa yang tidak diajar dengan menggunakan media permainan bahasa Arab diterima. Konsekuensi dari diterimanya $\mathrm{H}_{0}$ maka $\mathrm{H}_{1}$ yang berbunyi: ada perbedaan yang signifikan antara kemampuan membaca bahasa Arab mahasiswa yang diajar dengan menggunakan media permainan bahasa Arab dan mahasiswa yang tidak diajar dengan menggunakan media permainan bahasa Arab ditolak. Dengan demikian, dapat disimpulkan bahwa penggunaan media permainan bahasa Arab dalam pembelajaran membaca tidak efektif. Akan tetapi temuan ini membuktikan bahwa kemampuan membaca mahasiswa kelas kontrol sangat baik. Walaupun tidak diberi perlakuan dengan menggunakan media permainan bahasa Arab - dalam meningkatkan kemampuan membaca bahasa Arab - tidak berpengaruh sama sekali. Sedangkan pada kelas eksperimen kemampuan membaca bahasa Arab sebelum diberi perlakuan dengan menggunakan media permainan bahasa Arab kurang baik.

\section{Simpulan}

Berdasarkan hasil analisis data dalam hasil temuan dan pembahasan sebelumnya, dapat disimpulkan bahwa penggunaan media permainan bahasa Arab tidak efektif dalam pembelajaran kemampuan membaca bahasa Arab mahasiswa semester II program studi Pendidikan Bahasa Arab Fakultas Bahasa dan Sastra Universitas Negeri Makassar. Hal ini dibuktikan dengan berdasar pada tabel.11 bahwa nilai sig. (2 tailed) dari Post-test Kelas A dan Post-test Kelas B adalah 0.50, nilai sig. $=0.05$ sehingga dapat disimpulkan bahwa $\mathrm{H}_{0}$ diterima maka tidak terdapat perbedaan yang signifikan antara Post-test Kelas A dan Post-test Kelas B. Namun temuan ini membuktikan bahwa kemampuan membaca mahasiswa kelas kontrol sangat baik sehingga walaupun tidak diberi perlakuan dengan menggunakan media permainan bahasa Arab tidak berpengaruh sama sekali. Sedangkan pada kelas eksperimen kemampuan membaca bahasa Arab sebelum diberi perlakuan dengan menggunakan media permainan bahasa Arab kurang baik. Dan setelah diberi perlakuan, terdapat perbedaan yang sangat signifikan dalam nilai pre-test dan post-test kelas eksperimen.[]

\section{Daftar Rujukan}

Abdullah, Umar As-Siddiq. 2008. Ta'Tim al-Lughah al-'Arabiyah li an-Nāthiqīn bi ghairihā (atThuruq - al-Asā̄ib - al-Wasāil). Al-Jeeza: Dār al-'Alamiyah li an-Nasyr wa at-Tauzi’.

Alwasilah, Chaedar. 2010. Filsafat Bahasa dan Pendidikan. Bandung: Remaja Rosdakarya.

Alwi, Hasan. 2007. Kamus Besar Bahasa Indonesia. Jakarta: Balai Pustaka.

Asrori, Imam. 2013. 1000 Permainan Penyegar Pembelajaran Bahasa Arab. Malang: CV. Bintang Sejahtera Press.

Asrori, Imam. \& Moh. Ahsanuddin. 2015. Media Pembelajaran Bahasa Arab Dari Kartu Sederhana sampai Web Penjelajah Dunia. Malang: CV. Bintang Sejahtera. 
Arabi : Journal of Arabic Studies

Bahruddin, Uril. 2017. Rekonstruksi Pengembangan Pendidikan Bahasa Arab. Sidoarjo: CV Lisan Arabi.

Dalman. 2014. Keterampilan Membaca. Jakarta: PT. Rajagrafindo Persada.

al-Fauzan, Abdur Rahman bin Ibrahim. 2011. Idhä'at li mu'allim al-Lughah al-'Arabiyah li ghair an-Nāthiqūin bihā. Riyadh: al-'Arabiyah li al-Jāmi'.

Ketong, Sriyani. Burhanuddin \& Wahyu Kurniati Asri. 2018. "Keefektifan Model Pembelajaran Reciprocal Teaching Dalam Kemampuan Membaca Memahami Siswa Kelas XI IPA SMA Negeri 11 Makassar", Eralingua: Jurnal Pendidikan Bahasa Asing dan Sastra, Vol. 2, No. 1.

Mujib, Fathul. \& Nailur Rahmawati. 2011. Metode Permainan-Permainan Edukatif dalam Belajar Bahasa Arab. Jogjakarta: Diva Press.

Mujib, Fathul \& Nailur Rahmawati. 2013. Permainan Edukatif Pendukung Pembelajaran Bahasa Arab (2). Jogjakarta: Diva Press.

Rosyidi, Abd Wahab. \& Mamlu'atul Ni'mah. 2011. Memahami Konsep Dasar Pembelajaran Bahasa Arab. Malang: UIN Malang Press.

Setyosari, Punaji. 2015. Metode Penelitian Pendidikan \& Pengembangan. Jakarta: Prenadamedia Group.

Sugiyono. 2010. Metode Penelitian Pendidikan (Pendekatan Kuantitatif, Kualitatif, dan $R \& D$ ). Bandung: Alfabeta. 